\title{
The potential of career management competencies for renewed focus and direction in career education
}

\section{KAREN VAUGHAN}

\begin{abstract}
Career management competencies have recently emerged in New Zealand and in international policy addressing people's capabilities to build successful (working) lives in de-industrialised, knowledge societies. This article shows how career management competencies could address three major and long-standing problems with New Zealand school-based career education - inequitable access, marginalisation, and lack of fitness for purpose. It argues for an overall shift from careers information and guidance delivery to longer-term capability building. The article discusses a possible role for career management competencies in relation to the key competencies of the New Zealand curriculum. It also outlines how subject teachers, careers advisors, and industry could work together to provide the kinds of learning opportunities and pedagogies needed by today's young people making the transition from school to work and further learning.
\end{abstract}

Career management competencies have recently emerged in $\checkmark$ New Zealand and in international policy addressing people's capabilities to build successful (working) lives in de-industrialised, knowledge societies. As a set of understandings, skills, and attitudes, career management competencies make particular sense in societies characterised by growing occupational diversity and flexibility, geographical mobility of work and workers, rapid technological change, and labour market unpredictability. The concept of "career" is therefore no longer an outcome - finding and getting a job - and the concept of career guidance is no longer a test-for-aptitudes and match- 
to-job exercise. Instead, career is recognised as an evolving sequence of life experiences over time (Arthur, Inkson, \& Pringle, 1999), and these require ongoing management. For some people, that management may make their careers "protean" in form - increasingly managed by the learner or worker rather than only by the organisation for which they work (Hall \& Mirvis, 1996). For others, such management may mean focusing on their ongoing employability, even after finding a job. Either way, all individuals are now challenged to carefully coordinate their life, work, and learning choices and experiences, at all ages and stages throughout their lives.

This situation constitutes a new balance of responsibilities between individuals, employers, and state (Field, 2000), making the individual a stakeholder in the drive for economic growth (Lynch, 2008). For young people learning about careers, this manifests as a responsibilisation (Ball, Maguire, \& Macrae, 2000), casting them as both the problem and solution of their own transition from school (Vaughan, Roberts, \& Gardiner, 2006). In the economic and social terms of governments, the costs of unemployment or of people working in unfulfilling jobs and not realising their potential are high and well documented. Global labour market pressures and the employability of increasingly diverse populations mean that governments are now challenged to provide the tools with which people can co-ordinate and manage their life, work and learning.

To date, a version of these tools for life, work and learning has been formally provided through school-based career education. This is mandated under New Zealand's National Administration Guidelines (NAGs) (Ministry of Education, 2010) for schools, which specify that schools must:

provide appropriate career education and guidance for all students in year 7 and above, with a particular emphasis on specific career guidance for those students who have been identified by the school as being at risk of leaving school unprepared for the transition to the workplace or further education/training. (NAG 1(f))

The Ministry of Education provides secondary schools with a Careers Information Grant (CIG) to assist with associated costs in career education. It also provides Secondary-Tertiary Alignment Resource 
(STAR) funding to support short introductory courses, longer learning programmes at tertiary level, and courses offering industry-based standards at levels 1, 2, and 3. The Tertiary Education Commission provides schools with funding to run the Gateway Programme, offering students a mix of classroom-based and workplace-based learning programmes towards industry qualifications.

New Zealand schools are self-managing, so career education staffing and the content and configuration of career education programmes vary. However, there is always one designated careers advisor (usually a registered teacher) who coordinates careers activities. In larger schools, there may be a "pathways" or "transition" team, which often includes a guidance counsellor and various coordinators of workplace-liaison and tertiary-level learning programmes. Career education activities are offered to all students by year level, to some students according to prioritised groups, and/or on an as-and-when-required basis, instigated by the individual student or a teacher.

The careers advisor and/or team oversee the collection and supply of tertiary education and employment information, career planning resources and tools, and school leaver destination data. They coordinate work experience or vocationally-oriented courses or programmes, student visits to tertiary campuses and career expos, and the development and delivery of classroom-based career education activities (sometimes linked to school subject choice and planning). They also build and manage networks with community, industry bodies, employers, and tertiary education institutions, and offer oneon-one careers guidance sessions to students.

There are, however, major problems with the current approaches, including very long-standing ones and some that are not unique to New Zealand. ${ }^{1}$ And although many of the problems are well recognised, attempts to address them over the years have tended to suffer from a lack of shared vision, practical coordination, and sustainable approaches across those involved (including schools, families, government agencies, industry and employer representatives, and other community groups). In the following section, the major problems with career education are categorised into three main areas - 
inequitable access, marginalisation, and lack of fitness for purpose. Understanding how these flaws operate helps us to understand the potential of career management competencies to provide career education with a more promising direction and focus.

\section{Career education's three major flaws}

\section{Inequitable access}

The first flaw is that very few students in a school ever receive, or engage with, career education. STAR courses and Gateway programmes usually involve only a small proportion of a school's students and are frequently seen by teachers and parents as an intervention for less academically-able students (though in fact they can be used to extend able students). Moreover, those programmes are timetabled in ways that preclude students from combining these vocationally-oriented courses with other, traditionally academic ones (Hipkins, Vaughan, Beals, Ferral, \& Gardiner, 2005) and can restrict students' pathway options for tertiary education (Madjar, McKinley, Seini Jensen, \& Van Der Merwe, 2009).

Students also report a disturbing level of non-participation in career education. Over half of the respondents in the Competent Learners at 16 study (Wylie \& Hodgen, 2007) could not evaluate the usefulness of careers activities in their school because they had never experienced or participated in them - even though they were senior secondary school students and could have been expected to have had some experience of career education by that stage of their schooling (Vaughan, 2008b). In 2007, school careers staff reported on participation in careers activities by senior secondary students. Their estimates by year level for a range of listed careers activities were for participation rates of just 22-38 percent for Year 11 students and 36-52 percent for Year 12 students (Vaughan \& Gardiner, 2007). Some schools surveying their own students have found that they did not even know where the school careers office was located (Education Review Office, 2008). 
There is also evidence that some school principals do not direct their schools' STAR and CIG funding to their careers advisors and STAR coordinators ${ }^{2}$, and/or do not involve them in decisions about careers-related spending priorities, and the funding arrangements do not require this to happen (Vaughan \& Gardiner, 2007; Vaughan \& Kenneally, 2003). Other evaluations of career education have found its delivery and management to be idiosyncratic and inequitable (Wilson \& Young, 1998), and unlikely to improve without support because schools are weak in reviewing their own career education provision and therefore unable to evaluate its effectiveness (Education Review Office, 2006).

\section{Marginalisation}

The first flaw is underwritten by a second: career education tends to be seen as peripheral to the school's functioning and goals. Sometimes this is because career education activities are more likely to occur near the end of a student's schooling or for the most senior students. It can also be marginalised by its association with vocationally-oriented pathways which are typically lower status than academic pathways. The careers office may be located in an out-of-the-way space within the school and only visited by students at the instigation of students or another teacher. Careers staff are also marginalised. In a comparison of data from a 2007 national survey of careers staff and a 2006 national survey of teachers (Vaughan \& Gardiner, 2007), careers staff were shown as tending to be older and to have been teaching for longer than other teachers. The 2007 survey also found that careers staff were usually only part time in the role, and struggled to find enough time for the job and for managing new demands on their skills. In addition, very few careers advisors held careers-specific qualifications, and they were not legally required to. A lack of clarity around the role, training expectations, and professional identity has existed since the establishment of the careers advisor position in 1948, and anecdotal evidence suggests that the position has often been used by schools to "reward" teachers on their way to retirement or sideline those tired of classroom teaching (Vaughan \& O'Neil, 2010). 
Raising the status of career education and professional capacity of careers advisors by encouraging and supporting a school-wide focus on career education was a specific aim of the Ministry of Educationled Creating Pathways and Building Lives (CPaBL) initiative. ${ }^{3}$ However, $\mathrm{CPaBL}$ involved less than a third of all secondary schools and ran for just two years (2006-2007). New resources continue to be developed though, and the lessons learned and good practice developed through $\mathrm{CPaBL}$ continue to be disseminated (Education Review Office, 2009; Hodgetts, 2009). Other new initiatives and policies related to career education continue to be developed or supported by the Ministry of Education and Careers New Zealand. ${ }^{4}$ It remains to be seen whether and how other schools can develop and sustain some of the more successful approaches that emerged through $\mathrm{CPaBL}$, while the overall position of career education in so many schools is so marginal.

\section{Lack of fitness for purpose}

The third and perhaps most significant flaw is that the overall framework for careers work in many schools is not fit-for-purpose in today's world. Many careers activities are still rooted in a system that derived from early 20th century concerns with industrial expansion, occupational diversification, and the inability of family and neighbourhood to continue serving as a primary source of career information or job allocation (Herr, Cramer, \& Niles, 2004). However, the assumptions of this approach - individualised and unconstrained choices, a meritocratic and fair world of work, and a belief that work is the most important thing in people's lives - have helped produce conceptualisations of career as a fixed sequence of stages.

This type of conceptualisation has produced careers-related practices which attempt to predict and manage work and life choices through career planning activities and vocational aptitude and identity tests (Gysbers, 2003, cited in Capuzzi \& Stauffer, 2006). Not only are the assumptions on which these sorts of practices are based culturally value-laden and biased, with an elitist overtone - the well-educated corporate man tracking his way to the top (Watts, 2004) - but they are out of step with today's world because they assume a predictability 
which is based on a notion of stability in self, occupation, and labour market (Savickas et al., 2009). These assumptions have led to the prioritisation of the collection and distribution of information. Information about student interests and ability, determined by school achievement results, is then matched to information about current tertiary education and labour market opportunities. It is not surprising then that careers staff have reported ensuring access to information and distribution of information as their main priority. Teaching longer-term career management strategies and skills that are arguably more fit-for-purpose in today's world is rarely part of current practice (Vaughan \& Gardiner, 2007).

Of course, up-to-date information about tertiary education and the labour market is critical to good decision-making. However, digital technologies, mass communication, social networking and modern marketing strategies mean that we are now awash with information about an ever-increasing volume of possibilities. This situation can be overwhelming for young people. New Zealand school leavers report feeling confused by tertiary education and employment information, and lacking the capability to make sense of the information in order to make good decisions (Higgins \& Nairn, 2006; Vaughan, 2005; Vaughan et al., 2006). Their sentiments echoed those of young people in Australia and England (Ball, et al., 2000; Stokes, Wierenga, \& Wyn, 2004). Career education cannot just be about providing information, especially when so much of it is little more than marketing material.

\section{The emergence of career management competencies}

What the flaws in career education highlight is that much of the context for career education - certain occupations and labour market arrangements, skills and competencies required for work and life, people's aspirations, and the state's ability to provide security to citizens - has changed, while the career education framework remains as it was. This suggests that we need something more than additional resources, more planning activities, or another way to gather, 
distribute, and match information. These may fill some important gaps in the short term, but to make those or any other changes really useful, we need an altogether different career education framework.

Career management competencies may just be this new framework. Recently the New Zealand Ministry of Education and its Crown Agency, Careers New Zealand ${ }^{5}$, redeveloped guides to career education for schools, placing explicit emphasis on the needs of young people in the 21st century, and defining three career management competencies for a set of "understandings, skills and attitudes required to successfully manage life, learning and work" (Ministry of Education, 2009, p. 7):

- Developing Self-Awareness - about building and maintaining a positive self-concept; interacting positively and effectively with others; and changing and growing throughout life.

- Exploring Opportunities - about participating in lifelong learning to support life and work goals; locating information and using it effectively; and understanding the relationship between work, society and the economy.

- Deciding and Acting - making life and career-enhancing decisions; making and reviewing learning and career plans; and acting appropriately to manage careers.

New Zealand's development of career management competencies closely followed that of Australia's Blueprint for Career Development (Ministerial Council on Education Employment Training and Youth Affairs, 2010) which was developed between 2003 and 2008 and defined career management competencies as something more than technical skills and abilities and as involving "skills, knowledge and attitudes to make good career moves" which can be "developed and strengthened over time"6. In turn, the Australian Blueprint was modelled on the Canadian Blueprint for Life/Work Designs (National Life/Work Centre, 2010) for which development began in 1998, closely following a model developed as the United States National Career Development Guidelines ${ }^{7}$ (NCDG) Framework (National Career Development Association, 1993). The Canadian Blueprint captures a range of capabilities to be developed and located in the 
individual, emphasising intentionality and proactivity in managing life and work. The New Zealand, Australian and Canadian career management competencies are also closely related to those used in European countries. These are known as career management skills but defined as " $a$ whole range of competences ${ }^{8}$ which provide structured ways for individuals and groups to gather, analyse, synthesise and organise self, educational and occupational information, as well as the skills to make and implement decisions and transitions” (European Lifelong Guidance Policy Network, 2010, p. 23, emphasis added).

All of these career management competencies have taken their cue from the notion of key competencies, developed by the OECD to describe the kinds of things that all people need for contemporary life. Like the basis for key competencies, career management competencies acknowledge a 21st century knowledge society and changed conditions for life, career and work. They also stress the need for people to learn, attain and maintain intentionality about their work and education choices, take a meta-cognitive view, and learn to apply learning to different situations.

Significantly, all the career management competency definitions also position skill as just one dimension of competency needed. Unlike the emphasis in skills on possessing knowledge or the ability to do something, competencies emphasise performance and mobilisation of the skill or knowledge in specific contexts. As with the OECD's key competencies, prominence is given to learning that can be demonstrated in both today's demanding contexts or in contexts that are currently unfamiliar to us (Rychen \& Salganik, 2003). The subsuming of skills into competencies is the "something more" aspect of competencies which necessarily involve attitudinal and values dimensions, as well as those of knowledge, combined in ways that lead to action (Hipkins, 2008).

A particularly useful way to think about competencies, then, is to think of them as capabilities (Hipkins, forthcoming; Ministry of Education, 2007) in the sense of education being about supporting young people to become who they are capable of being and to do what they are capable of doing (not just what they are capable of knowing or holding in their heads). In career education terms, this echoes 
longitudinal research findings on young people approaching early career development in terms of who they can be, rather than simply what occupation they might enter (Vaughan et al., 2006). It suggests a necessary move in career education away from delivery (of information and pre-packaged work experience) towards capability building for considering possibilities and taking action throughout life as individual and societal situations and priorities change over time (Vaughan, 2008a).

\section{Competencies and the New Zealand curriculum}

Career management competencies have the potential to address career education's structural flaws of inaccessibility, marginality, and lack of fitness for purpose through their conceptualisation in terms of learning-to-learn, meta-level and transferable learning, and their applicability to all learners. Since they constitute a broad framework rather than a prescription, they can work well with the existing key competencies in the New Zealand Curriculum (NZC) (Ministry of Education, 2007): managing self, thinking, participating and contributing, relating to others, and using language, symbols and texts $^{9}$. The NZC positions competency as the key to learning in any field and "both an end in itself (a goal) and the means by which other ends are achieved" (Ministry of Education, 2007, p. 12). In other words, students both learn to be competent in five key dimensions (the end or goal) through various social contexts (which demand the combined use of skills, attitudes, values, and knowledge) and they learn other specific things (e.g., how to write a well-argued essay, how photosynthesis works) through a focus on competency development.

Rather than adding three more competencies to the key competencies, the Ministry of Education describes career management competencies as reflecting the NZC's overall vision and values, and as having a relationship with the key competencies. It provides the following table to illustrate what such a relationship might look like (see Table 1). It shows, for example, that the career management competency of developing self-awareness has a particularly close relationship with the key competencies of managing self and relating 
to others. The key competency of participating and contributing is shown matched with the career management competency of deciding and acting.

\begin{tabular}{|l|l|}
\hline Career management competencies & Link to the key competencies \\
\hline $\begin{array}{l}\text { Developing self-awareness - young } \\
\text { people understand themselves and the } \\
\text { influences on them. }\end{array}$ & $\begin{array}{l}\text { Involves managing self and relating to } \\
\text { others. }\end{array}$ \\
\hline $\begin{array}{l}\text { Exploring opportunities - young } \\
\text { people investigate opportunities in } \\
\text { learning and work. }\end{array}$ & $\begin{array}{l}\text { Requires students to think critically, } \\
\text { use language, symbols and texts, and } \\
\text { relate to others. }\end{array}$ \\
\hline $\begin{array}{l}\text { Deciding and acting - young people } \\
\text { make and adjust their plans, manage } \\
\text { change and transition, and take } \\
\text { appropriate action. }\end{array}$ & $\begin{array}{l}\text { Involves students thinking } \\
\text { constructively and preparing to } \\
\text { participate and contribute throughout } \\
\text { their lives. }\end{array}$ \\
\hline
\end{tabular}

Table 1. Links between career management competencies and key competencies

Just as teachers at "early adopter" schools have used plain language translations of key competencies to link to already familiar ideas in their own schools (Hipkins, 2010b), these matches of key competency to career management competency provide a helpful way to begin to think about the two sets of competencies. This is how they were first introduced to teachers participating in the Digital Pathways Development (DPD) professional learning, where the table was adapted and colour-coded for teachers new to working with career management competencies. However, these matches may be misleading as an approach to teaching and learning for competency development longer term (and DPD is currently rethinking these matches for its work in some schools). Both the NZC and recent research suggest that, in practice, key competencies are mostly used in combination. One study shows that teachers initially see particular learning areas having a more natural fit with particular key competencies before moving on to actively explore how to build up the links between subjects and competencies (Hipkins, Cowie, Boyd, Keown, \& McGee, 2011). Another study on reading and using language, symbols and texts found that: 
As the research progressed it became more and more clear that, regardless of which key competency was foregrounded, the same ideas surfaced. That is, we found that there is a group of ideas that do not "go" more comfortably with one key competency, but rather, it is more the case that they are engaged when any of the five key competencies is being modelled and discussed. (McDowall \& Twist, 2010, p. viii)

It may be most useful, then, to think of one set of competencies (key or career management) as always implicating the other. So students would learn to be competent at the five key dimensions (as the competency building blocks) and the three careers-specific dimensions, with all of them woven through each other and all of the other learning opportunities and subject areas. Figure 1 illustrates one possible interpretation of the career management competencies/key competencies relationship.

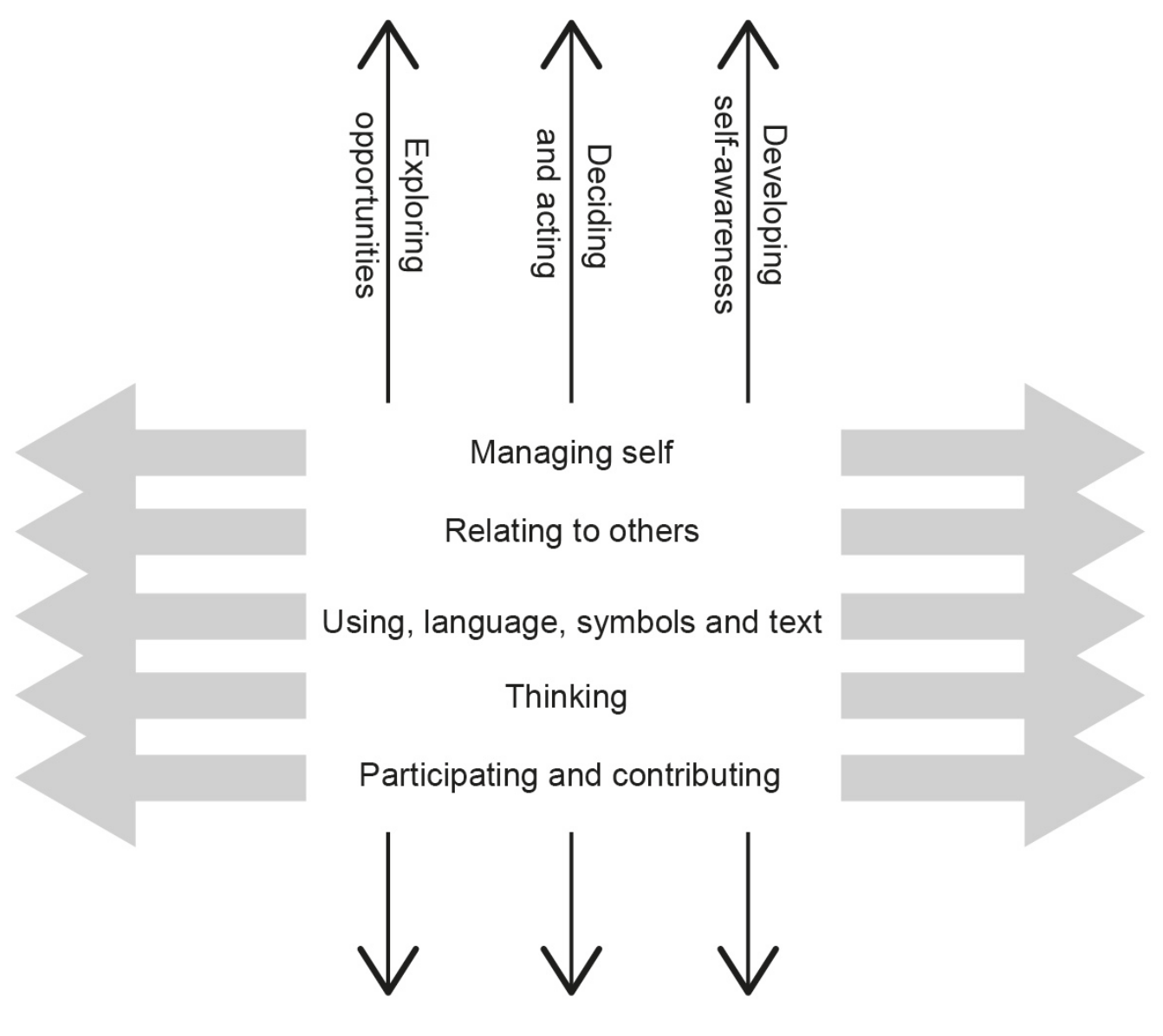

Figure 1. Co-implicated career management competencies and key competencies 


\section{New learning and teaching opportunities}

Seeing both sets of competencies as co-implicated, and understanding that many competencies are simultaneously engaged when someone is learning, opens up new and different teaching and learning opportunities. Competencies cannot be taught or learned directly, isolated from meaningful contexts. They instead require rich learning contexts (e.g., subject areas with engaging opportunities to learn). They then lead to somewhat different learning outcomes for students. The idea is to emphasise a critical approach to information and knowledge, and to help students to know about learning (disciplinary thinking) and how they themselves best learn (and being able to articulate that), as well as integrating skills with attitudes, knowledge, and values so that students are able to adapt their competencies for use in new situations and know how, why, and when to do this (Hipkins, 2007). This points to an understanding of learning as participation, rather than as acquisition (Sfard, 1998). Learning as acquisition, which dominates educational institutions and other formal learning contexts, assumes that knowledge exists "out there" and is acquired by the individual knower. A learning-as-participation view, on the other hand, sees knowledge as situated and continually (re)produced through relationships and interactions between individuals (Lee et al., 2004).

This is a helpful framework for thinking about career education because it lends itself to situated and authentic learning, and establishing relevance of learning through validation of students' informal (non-school-based) learning. Although the way career education is often organised in schools means that careers advisors tend to prioritise provision of advice and information, a significant proportion of career education involves opportunities in experiencebased and participation-oriented learning. For example, some students are offered work experience days, "taster" courses, and structured workplace learning programmes, and may visit tertiary education campuses and listen to former students, community members, and industry representatives talking about their own pathways and occupations. 
What is often missing from these activities, and what leaves them at the level of pre-packaged material and hands-on experience, rather than competency or capability-building, is an emphasis on static skills (e.g., making a curriculum vitae, safe use of power tools), information collection (e.g., brochures on different tertiary programmes) and trying out things (e.g., assisting in a hairdressing salon) to see what might appeal to students' interests and aptitudes. This is useful, but only as a first step. Giving students opportunities to really develop competencies would involve teaching in new ways that focus not only on subject content (the history textbook or gathering tertiary course information or gaining hands-on experience in a workshop), but also on learning-to-learn and reflective strategies.

Reframing these participatory experiences with learning-to-learn and reflective strategies involves going a step further than the typical current practice. For example, a careers advisor (or another teacher) would not just suggest options for employment to a student but would explore with them what employability throughout their life could mean. The careers advisor or workplace liaison coordinator might not stop at organising programmes of hands-on workplace-based learning that best suit students' interests, but might also support those students to use digital and web-based technologies to reflect on their experiences and their meaning in their lives.

For subject teachers in classrooms, these strategies would involve focusing “on more deliberately working with students' current understandings and giving them time to think and talk about how they are learning” (Hipkins, 2010b, p. 13, emphasis added). A science teacher might not just put up a poster about science-related careers in their science classroom. They might also engage students in authentic experiences of scientific work and support them to engage with science communities of practice so that students can make real meaning from the information in the poster.

In other words, students should learn and reflect on their learning processes (Ministry of Education, 2007) in all of their learning contexts. If students are supported to do this, their reflexive connections become a kind of "boundary crossing" where they draw upon both their formal (at school) and informal (at home, in life) 
experiences and learning (Wesselink, de Jong, \& Biemans, 2010, p. 25). These boundaries are increasingly acknowledged as needing crossing in knowledge societies, as the dominance of traditional education institutions and traditional learning opportunities is challenged and recognition grows for the value and relevance of other learning contexts, including the workplace (Gruber, Mande, \& Oberholzner, 2008). Just as the world of work now increasingly demands that people manage their own careers and ongoing learning, the development of career management competencies means providing the conditions and support for students to become central to, and responsible for, their own learning. A competencies approach is not just edu-speak then. It has real meaning in the "real" world.

None of this is to say that classroom subject content (e.g., what is taught in social studies) and disciplinary knowledge (e.g., how to think scientifically or historically) are unimportant. It is just that knowledge and skills "need to be augmented with dispositions and qualities” (Barnett, 2009, p. 440). That is, learning to learn and coming to be in the world depend on learning something in depth, such that the nature of knowledge (its fragility, how it came to be, how it functions) is also understood (Egan, 2010). Students still need to have a serious encounter with knowledge in order to develop dispositions such as a will to learn, a preparedness to explore, and a determination to keep going forward (Barnett, 2009) and so learn about themselves.

\section{New roles and partnerships}

Not only does a competencies approach open up new learning opportunities, it also opens up the possibility of different people within a school and within a community becoming involved in career education. This partly depends on how the provision of learning opportunities is structured. Sultana (2011) suggests four possibilities for career management skills in schools: 
1. as a separate subject (compulsory or optional)

2. as a theme compulsorily contained within, or mobilised through, every subject

3. as extra-curricular activities or workshops delivered at particular points in time

4. as a boundary-breaker between school and other dimensions of students' lives (e.g. utilising the non-formal and informal learning contexts in which students live and work every day).

Schools already provide career education through structures in the suggested options 1 and 3 but these tend to suffer from the flaws discussed earlier in this article. They also tend to reinforce the idea that career education is distinct from what the rest of school is about.

The second and fourth options seem to offer the most productive space for competencies in New Zealand, and fit well with the Ministry of Education and Career New Zealand's suggestion that schools take a whole-school approach to career education by integrating career management competencies throughout the curriculum. This would constitute a change to current in-school relationships. For example, instead of the sole possibility of sending students to the careers advisor for one-to-one guidance, teachers might work alongside careers advisors to think about the needs of particular students and how they could be addressed through class activities. Teachers might also work together across learning areas to create rich learning contexts for students. Careers advisors might take on a coordinating role with teachers across the school, working with them to create specific points of engagement with careers and drawing on careers resources and tools already used or accessed by the school (e.g., tertiary education and labour market information, interactive careers games, subject-career matching tools). Some careers advisors already use a decentralised network model in order to help manage the complex and numerous relationships and information sources that existing organisational structures or hierarchies may not directly support (Vaughan \& O'Neil, 2010). 
These sorts of new relationships within the school are likely to pose huge challenges. First, subject teachers may resist involvement in career education. The suggestion that "all teachers are career teachers" (Ministry of Education, 2007, p. 25) is asking subject teachers to take responsibility for something that is commonly regarded as the responsibility of one designated person. The CPaBL evaluation (Education Review Office, 2009) found this to be one of the biggest challenges - getting teachers to recognise the importance of career education and to recognise their own role in providing relevant information and guidance.

A second challenge is that careers advisors may struggle to gain any traction with other staff because of their general lack of status and influence in the school. Change might also feel threatening to them if they have become attached to an older model of career guidance - one that is organised around things that were scarce, such as labour market information, tertiary institution information and vocational testing. With these things now readily available through websites, marketing material, private companies and online self-testing resources, they no longer reside in the sole domain of the careers advisor, and it is not so clear what careers advisors should be doing, whether they can do it, or how they can be supported to do it (Vaughan \& O'Neil, 2010).

It is clear from other research that changes of this order require a significant commitment by the government and by teaching staff to professional development. Many of the 100 schools involved in the $\mathrm{CPaBL}$ initiative used their funding on professional development and this was usually related to attempts to integrate careers information into subject teaching, pastoral care/tutor roles, and ways to access careers information (Education Review Office, 2009). Recent research on key competencies in New Zealand primary and secondary schools also found that "iterative cycles of learning" (Hipkins et al., 2011, p. 36) are necessary for schools to connect explorations of key competencies to earlier professional learning. It would seem to be too soon to see discipline-specific changes to teaching and learning, although teachers are beginning to recognise what might be involved in competency development, including that lifelong learning might apply to them as well as to students (Hipkins et al., 2011). 
New roles and partnerships between schools and communities are another possibility. Many schools already have relationships with employers and community groups. Some are fostered informally through teachers' and parents' connections. Others occur formally through the Gateway programme, STAR courses, national competitions and initiatives (e.g., the Smokefree Stage Challenge, and Education for Sustainability) and schemes run by industry training organisations and tertiary education providers (e.g., the Bright Sparks electronics club, and the Build-Ability Challenge competition).

Reframing these school-community relationships in terms of competency or capability development is likely to involve explicit agreements about the point of school-workplace learning and of learning itself. It makes sense for teachers to lead and maintain overall responsibility for the learning context and opportunities for students. Although learning is increasingly recognised by businesses as a key indicator and driver for productivity, rather than the front-loaded and school-based opposite of it, the imperatives of learning and production can frequently conflict (Vaughan, 2008c). Teachers may need to balance the different interests (and sometimes self-interests) involved in school-work partnerships: employers looking for employees; industry representatives looking to grow and sustain the industry; industry training organisations securing trainees and Standard Training Measure grants; and tertiary education providers recruiting students and gaining Equivalent Full-Time Student funding (Tertiary Education Commission, 2003; Vaughan \& Kenneally, 2003).

Teachers, workplace coordinators, and employers may also need to cooperate with explicit strategies for working with the students in these programmes. Although there is some acknowledgement of the workplace in providing valuable learning opportunities, processes, and outcomes, they are still generally seen as places where practice can be experienced, rather than essential learning experiences in their own right (Billett, 2008). The close association between learning and the classroom means that students who are attracted to workplace contexts often lack confidence in their learning ability and see a community or workplace context as a way to avoid learning (Vaughan, 2010). One recent study shows that, in addition to the interests of non-school 
partners, students commonly think they are learning-by-doing and that reflection is not part of the learning process unless teachers and workplace training supervisors challenge and support them to do it and teachers take overall responsibility for students' competence development (Wesselink et al., 2010).

\section{Conclusion}

There is great potential in New Zealand's competencies approach to learning to address the flaws of inaccessibility, marginality and lack of fitness for purpose in career education. The inherent relevance and future-focused content and context of career education lends itself to competency development and to "the development of rich and diverse learning opportunities for students to develop and demonstrate the key competencies" (Ministry of Education, 2009, p. 11). The key competencies of The New Zealand Curriculum (Ministry of Education, 2007) provide a means to integrate career education more fully into the school.

It may also work the other way around. There is evidence that career education is valuable in increasing student engagement, participation, and retention in school (Hooley, Marriott, \& Sampson, 2011; Plank, DeLuca, \& Estacion, 2008; Stokes, Wierenga, \& Wyn, 2003). So career management competencies might play a part in renewing the direction of schools generally by providing a sharpened focus to the overall principles of the NZC - high expectations for all students, the Treaty of Waitangi, cultural diversity, inclusion, learning to learn, community engagement, coherence, community engagement, and future focus - and to the overall vision of young people becoming confident, connected, actively involved lifelong learners (Ministry of Education, 2009).

Although career management competencies have the potential to sharpen the focus and purpose of the school, and highlight the relevance of school or particular subjects for students, it is not simply because school is mainly about preparation for the next transition and ultimately for the world of work. Career management competencies cannot simply become a way for teachers to meet students "where they're at" because doing this risks "leaving them exactly there" 
(Green, 1986, p. 115, cited in Avis, 1991, p. 117). Career management competencies should be about capabilities for a satisfying life, of which work comprises a very significant part - in terms of time and energy commitment and in terms of being a key way to participate in communities of practice and society at large. That means meeting students where they're at and helping them imagine more possibilities, further into their future, through new experiences. This is particularly important for students in at-risk groups who are more likely to be in vulnerable labour market positions. Current career education practices, underpinned by NAG 1(f)'s focus on at-risk students, tend towards short-term employment or tertiary enrolment solutions rather than additionally building longer-term capabilities. Ideally, students especially at-risk ones - who develop career management competencies will not so much be learning for work (where the individual must adapt to a situation) but be learning about work (and understanding themselves in context) (Simon et al., 1991, cited in Sultana, 2011).

So where does this leave us now? Because much of this is so new, there is little evidence about long-term impact. Despite policy consensus across Europe that career management skills are useful as part of school curricula, there is little hard evidence to back the optimism, and no knowledge of how in practice it will work (Sultana, 2011). Even the OECD's Skills Strategy project (Organisation for Economic Cooperation and Development, 2011) will inquire into what evidence there is that particular skills and competencies, beyond literacy and numeracy, can help workers obtain better labour market outcomes and cope with the fluidity of labour markets today. However, there are examples in recent research of teachers' attempts to take a competencies approach which include: making explicit links between key competencies and inquiry learning in ways that bring together subject areas; developing student curriculum leader groups; thinking about how to give students choice in learning contexts; and supporting students to reflect on their learning and progress through journals and e-portfolios (Hipkins et al., 2011). 
The non-prescriptive nature of competency development (and the NZC) means that it is up to schools to work out how to help people develop competencies by providing the learning contexts in which they can be developed. The self-managing structure of New Zealand schools may have contributed to some of the current unevenness of career education provision (Sultana, 2011; Vaughan \& O'Neil, 2010), but weaving career management competencies together with key competencies, integrating these throughout the school, and focusing them clearly on the development of capabilities for 21st century life may provide a way around this. This leads to an important social justice dimension in careers work - providing opportunities for all students, aligning careers work with school vision, and making career education fit-for-purpose in the 21st century. This is a complex work in progress.

\section{Acknowledgements}

I am grateful for the invaluable conversations on competency development with my research colleagues at NZCER, Rosemary Hipkins (who also provided feedback on this paper) and Lorraine Spiller, and for advice from Mark Dashper at the University of Auckland and Adie Graham at Massey University. I also acknowledge my colleagues in the wider project on education-employment linkages for youth transition in which this research is located: Jane Higgins, Paul Dalziel, and Hazel Phillips at Lincoln University. 


\section{References}

Arthur, M. B., Inkson, K., \& Pringle, J. K. (1999). The new careers: Individual action and economic change. London: Sage.

Avis, J. (1991). The strange fate of progressive education. In Department of Cultural Studies (Ed.), Education limited: Schooling and training and the New Right since 1970. Birmingham: University of Birmingham.

Ball, S. J., Maguire, M., \& Macrae, S. (2000). Choice, pathways and transitions post-16: New youth, new economies in the global city. London: Routledge Falmer.

Barnett, R. (2009). Knowing and becoming in the higher education curriculum. Studies in Higher Education, 34(4), 429-440.

Billett, S. (2008). Emerging perspectives on workplace learning. In S. Billett, C. Harteis, \& A. Etelapelto (Eds.), Emerging perspectives on workplace learning. Rotterdam: Sense.

Capuzzi, D., \& Stauffer, M. D. (2006). Career counselling: Foundations, perspectives and applications. Boston: Pearson.

Education Review Office. (2006). The quality of career education and guidance in schools. Wellington: Education Review Office.

Education Review Office. (2008). Implementation of the creating pathways and building lives ( $\mathrm{CPaBL}$ ) initiative. Wellington: Education Review Office.

Education Review Office. (2009). Creating pathways and building lives: Overall evaluation of the initiative 2006-2008. Wellington: Education Review Office.

Egan, K. (2010). Learning in depth: A simple innovation that can transform schooling. Chicago: The University of Chicago Press.

European Lifelong Guidance Policy Network. (2010). Lifelong guidance policies: Work in progress. A report on the work of the European Lifelong Guidance Policy Network 2008-10. Jyväskylä, Finland: European Lifelong Guidance Policy Network.

Field, J. (2000). Why lifelong learning promises so much but delivers so little. Educational Management and Administration, 28(3), 249-261.

Gruber, E., Mande, I., \& Oberholzner, T. (2008). Modernising vocational education and training: Fourth report on vocational training research in Europe: Background report. Vol 1. 2008. (Cedefop reference series 69-1). Luxembourg: European Centre for the Development of Vocational Training. 
Hall, D. T., \& Mirvis, P. H. (1996). The new protean career: Psychological success and the path with a heart. In D. T. Hall and Associates (Eds.), The career is dead: Long live the career: A relational approach to careers (pp. 15-45). San Francisco: Jossey-Bass.

Herr, E. L., Cramer, S. H., \& Niles, S. G. (2004). Career guidance and counselling through the lifespan (6th ed.). Boston: Pearson Education.

Higgins, J., \& Nairn, K. (2006). In transition: Choice and the children of New Zealand's economic reforms. British Journal of Sociology, 27(2), 207-220.

Hipkins, R. (2006, April). Key competencies: Challenges for implementation in a national curriculum. Paper presented at Key Competencies: Repackaging the old or creating the new? Wellington.

Hipkins, R. (2007). Assessing the key competencies. Why would we? How could we? Wellington: Learning Media.

Hipkins, R. (2008). The "something more" in key competencies. Set: Research Information for Teachers, 3, 35-37.

Hipkins, R. (2010a, October). More complex than skills: Rethinking the current relationship between key competencies and curriculum content. Paper presented at International Conference on Education and Development of Civic Competencies, Seoul.

Hipkins, R. (2010b, November). Introducing key competencies into a national curriculum framework: What have we learned in New Zealand? Paper presented at International Conference on the Key Competencies and Educational Innovation in a Global Era, National Taiwan Normal University, Taipei.

Hipkins, R. (forthcoming). Key competencies: A promising curriculum direction.

Hipkins, R., Cowie, B., Boyd, S., Keown, P., \& McGee, C. (2011). Curriculum implementation exploratory studies 2. Final report. Wellington: New Zealand Council for Educational Research and The University of Waikato.

Hipkins, R., \& Vaughan, K., with Beals, F., Ferral, H., \& Gardiner, B. (2005). Shaping our futures: Meeting secondary students' learning needs in a time of evolving qualifications. Wellington: New Zealand Council for Educational Research.

Hodgetts, I. (2009). Rethinking career education in schools: Foundations for a New Zealand framework. Wellington: Career Services. 
Hooley, T., Marriott, J., \& Sampson, J. P. J. (2011). Fostering college and career readiness: How career development activities in schools impact upon graduation rates and students' life success. Derby: International Centre for Guidance Studies (iCeGS), University of Derby.

Lee, T., Fuller, A., Ashton, D., Butler, P., Felstead, A., Unwin, L., et al. (2004). Learning as work: Teaching and learning processes in the contemporary work organisation. Leicester: University of Leicester.

Lynch, H. (2008). Lifelong learning, policy and desire. British Journal of Sociology of Education, 29(6), 677-689.

Madjar, I., McKinley, E., Seini Jensen, S., \& Van Der Merwe, A. (2009). Towards university: Navigating NCEA course choices in low-mid decile schools. Auckland: Starpath Project, University of Auckland.

McDowall, S., \& Twist, J. (2010). Lifelong literacy: The integration of key competencies and reading (Report prepared for Cognition Education Research Trust). Wellington New Zealand Council for Educational Research.

Ministerial Council on Education Employment Training and Youth Affairs. (2010). Australian Blueprint for career development. Retrieved November 3, 2011, from

http://www.blueprint.edu.au/AbouttheBlueprint/WhatareCareerManagement Competencies.aspx

Ministry of Education. (2007). The New Zealand curriculum. Wellington: Learning Media.

Ministry of Education. (2009). Career education and guidance in New Zealand schools. Wellington: Learning Media.

Ministry of Education. (2010). The National Administration Guidelines (NAGs). Retrieved November 3, 2011, from http://www.minedu.govt.nz/NZEducation/EducationPolicies/

Schools/PolicyAndStrategy/PlanningReportingRelevantLegislationNEGSAn dNAGS/TheNationalAdministrationGuidelinesNAGs.aspx

Ministry of Education. (2011). Ka Hikitia: Measurable gains framework rubrics 27/10/10. Retrieved from http://www.minedu.govt.nz/theMinistry/PolicyAndStrategy/KaHikitia/Meas uringandReportingProgress.aspx

National Career Development Association. (1993). Career development: A policy statement of the National Career Development Association. Retrieved November 3, 2011, from http://associationdatabase.com/aws/NCDA/pt/sp/guidelines 